\title{
Bone Marrow Stem Cell with Predominant Neutrophil Differentiation
}

National Cancer Institute

\section{Source}

National Cancer Institute. Bone Marrow Stem Cell with Predominant Neutrophil

Differentiation. NCI Thesaurus. Code C41060.

A primitive, undifferentiated blood cell which can undergo division and usually gives rise to a white blood cell in the neutrophil lineage. 